\title{
DEVELOPING OF GUIDED INQUIRY-BASED BIOCHEMISTRY PRACTICUM GUIDEBOOK
}

\author{
Diyah Ayu Widyaningrum* and Titik Wijayanti \\ Department of Biology Education, Faculty of Exact Sciences and Sports, IKIP Budi Utomo \\ Malang, East Java, Indonesia \\ *Corresponding e-mail: diyahayuwidyaningrum8905@gmail.com
}

\begin{abstract}
There were no practicum guidebook in Biochemistry hands-on activity at IKIP Budi Utomo, Malang city, East Java-Indonesia. The purpose of this study was to develop a guided inquiry-based biochemistry practicum guidebook for students of IKIP Budi Utomo. The development of guidebook followed the 4DThiagajaran model which has 4 stages, namely define, design, develop, and disseminate. The types of the data in this study were qualitative and quantitative. The qualitative data was obtained from the validator suggestions. The quantitative data was obtained through validator assessment scores and legibility tests. The instruments used to collect data included validation sheets and questionnaires. The results showed that the practicum guidebook validation percentages were $93.48 \%$ (material experts), $100 \%$ (learning media expert), and $81.5 \%$ (teacher) which were categorized as very feasible. It can be concluded that the biochemistry practicum guidebook is highly suitable to be implemented.
\end{abstract}

Keywords: Biochemistry, guided inquiry, practicum guidebook

(C) 2018 Department of Biology Education, FTTE, University of Muhammadiyah Malang, Indonesia

\section{INTRODUCTION}

Educators are expected to be able to develop competence in their profession. There are four kinds of competencies that educators must possess, including personal competence, social competence, pedagogic competence and professional competence. One of the pedagogic competencies was that educators are expected to be able to create and develop teaching materials in supporting the learning process. Teaching materials are materials or subject matter that were arranged systematically and used by teachers and students in the learning process (Munir \& Sholehah, 2018). Teaching materials are unique and specific. Unique, because teaching materials could only be used for certain audiences in a particular learning process. Specific, because the contents of the instructional material are designed in such a way as achieved certain objectives of certain audience (Sadjati, 2012).

Teaching materials were grouped into 7 types including printed teaching materials, display teaching materials, silent display teaching materials, audio teaching materials, audio teaching materials that were connected with silent visual materials, video teaching materials and computer teaching materials (Sadjati, 2012). Practicum was an activity learning aims so that students got the opportunity to test and apply theory using laboratory facilities and outside the laboratory (Suryaningsih, 2017). Practical instructions are guidelines written with the aim that students can learn independently or without the help of a teacher (Wahyuni, 2015). Practical instructions were instructions that must be followed by all practicum participants who will carry out practical activities. The practical guide aims to help the practitioner in practice. The practicum instructions made must be in accordance with the material taught so that the practicum can run as expected (Munir \& Sholehah, 2018). Biochemistry was one of the subjects that contained theory and practice. Biochemistry was a subject that studies chemical reactions in the body of living things.

The researcher carried out preliminary research, namely the analysis of the needed of teaching materials. Needed analysis was conducted on 2014 Biology education study program students who had taken Biochemistry courses. Needed analysis was done by giving a questionnaire once.The resulted of the needed 
analysis of the Biochemistry practicum guidebook on the lecturer showed that the available teaching material was only a textbook containing the theory and there was no practical manual. The practicum guidebook that was needed was the language and instruction that were easily understood and ably made students find concept independently with guidanced from educators.

The resulted of the needed analysis of the practicum guidebook on student indicated that the practicum guidebook has not been available during the learning process. The book needed is an easily understood step and stimulated students to work scientifically. Based on the resulted of the analysis of the needed of the Biochemistry course practical guidebook for student showed that as many as $92.9 \%$ of student expected practical instruction book whose language was easily understood and able made student worked scientifically.

Research on teaching material in the form of practical manual was conducted by (Zulaiha \& Ibrahim, 2014) regarding the development of a hydrocarbon chemistry practical guidebook based on science processed skill in high school showing very valid resulted from the three validators. A similar study conducted by Munika, Mujamil, and Desi (2014) regarding the development of inquiry-based acid base solution practicum instructions in the basic chemistry practicum II at the FKIP of Sriwijaya University showed valid results of 4 on pedagogical and highly valid aspects of 4.21 on design aspects.

The purpose of this study was to develop guided inquiry-based Biochemical practice manuals. The guided inquiry learning model was used because it was capable reflection in developing self-regulating learning skill and continuous support from teacher and teacher librarian (Garrison \& FitzGerald, 2016). The guided inquiry was a learning model that is able to accommodate the scientific work skills of students (Almuntasheri, Gillies, \& Wright T, 2016; Ibe, 2013; Sandika \& Fitrihidajati, 2018). The guided inquiry has problem identification syntax, hypothesis formulation, data collection, data interpretation, conclusion development and review (Joyce \& Weil, 2000).

\section{METHOD}

The development of learning tools carried out follows the 4D development model (Thiagarajaan, Semmel, \& Semmel, 1974). The
4D model has 4 stages, namely define, design, develop, and disseminate, while the research that would be carried out was limited to the developing stages. The development procedure consisted of a defined stage which consists of front-end analysis, student analysis, task analysis, concept analysis, and analysis of learning objectives. The next stage was designed which is done to produce a prototype of the development results.

The prototype of the development resulted in this study was an inquiry-based Biochemical practicum guidebook. The next step was developing. Learning material at the develop stage through several repairs before it was ready to be used by the user. The process of improving learning materials was based on the formative evaluation, one of which is through expert judgment. Formative evaluation activities for Biochemimistry practicum guidebook were carried out by material experts, media experts, and Biochemistry lecturers. The validator were showed in Table 1.

Table 1. The validator/expert and areas of expertise

\begin{tabular}{|c|c|c|}
\hline $\begin{array}{l}\text { Expert name } \\
\text { (Initials) }\end{array}$ & $\begin{array}{c}\text { Areas of } \\
\text { Expertise }\end{array}$ & Role \\
\hline NI & $\begin{array}{l}\text { Biotechnology and } \\
\text { Biochemistry }\end{array}$ & $\begin{array}{l}\text { Material } \\
\text { validator }\end{array}$ \\
\hline INQ & $\begin{array}{l}\text { Learning Media } \\
\text { and Microbiology }\end{array}$ & $\begin{array}{l}\text { Media } \\
\text { validator }\end{array}$ \\
\hline WAB & $\begin{array}{l}\text { Biochemistry and } \\
\text { Basic chemistry }\end{array}$ & $\begin{array}{l}\text { Field } \\
\text { practitioner }\end{array}$ \\
\hline
\end{tabular}

The final step in the developed stage was the product readability test. Readability test was carried out on classes that have taken Biochemistry courses, namely the 2014 class. The type of data in this study was qualitative and quantitative data. Qualitative data was obtained from the suggestions submitted by the validator. Quantitative data was obtained through validator assessment score and small scale test (legibility test). The instrument used for data collection include validation sheets and questionnaires (Thiagarajaan et al., 1974).

The percentage technique was used to present data which was the response frequency of the subject of the trial to the Biochemisgtry practicum guidebook product. The Formula 1 (Sugiyono, 2011) used to calculate the percentages of assessment results validator.

$\mathrm{P}=\frac{X i}{n} \times 100 \%$ 


\section{RESULTS AND DISCUSSION}

The Biochemistry practicum guidebook was developed follows the steps of the guided inquiry learning model. The contents of the guidebook include cover, preface, table of contents, description of courses, work safety standards, laboratory techniques, the practicum activities presented in each chapter, and bibliography and explanation of laboratory reports. The guidebook's cover can be seen in Figure 1.

The results of the studied were in the form of assessments from validator material experts, media expert validators, field practitioners, and readability tests on products. The full assessment resulted are presented in Table 2, Table 3, and Table 4.

Based on Table 2 could be seen that the average score for aspects of content eligibility is 3.82 with the appropriate category, the aspect of presentation eligibility is 3.79 with the appropriate category, the aspect of language feasibility is 3.63 with the appropriate category. Answers to supporting questions include: (a) Practicum guidebook could help students to understand the material of Biochemistry and the concept of Biochemistry through practicum activities. (b) The advantages of the practicum guidebook are equipped with work safety, the introduction of laboratory equipment, there were graduate learning outcome (or Capain Pembelajaran Lulusan/CPL) and achievement of course learning (Capain Pembelajaran Mata Kuliah or CPMK) and there was identification of problems that encourage student curiosity. (c) Weaknesses from the practicum guidebook should be complemented by the introduction of laboratory materials and their uses, added theoretical basis, and bibliography in each chapter. (d) Suggestions for the products developed are in the table of contents written in detail the title of each chapter and the official report format added to the bibliography and interim reports.

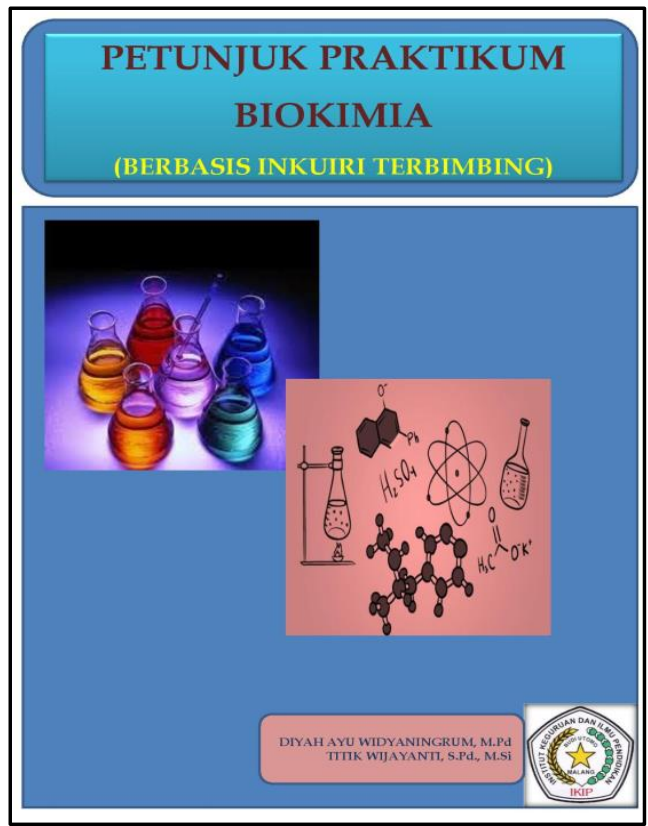

Figure 1. The cover of biochemistry practicum guidebook

Based on Table 3 it could be seen that the average score for the indicator size practicum instructions are 4 in the very appropriate category, the cover design indicator is 4 in the very appropriate category, the content design indicator is 4 in the very appropriate category, and the learning activity indicator is 4 in the category very appropriate. Product development advice was a practicum guidebook developed to facilitate students in practicing activities. The conclusion of product development was that practicum guidebook can be used with revisions. The conclusion was practicum guidebook could be used with revisions.

Table 2. Results of expert validator assessment material

\begin{tabular}{clcl}
\hline \multicolumn{1}{c}{ Aspect } & \multicolumn{1}{c}{ Indicator } & Score & Category \\
\hline \multirow{4}{*}{ Feasibility of Content } & 3,67 & Appropriate \\
& Suitability of the material with CPMK & 3,6 & Appropriate \\
& Material accuracy & 4 & Very appropriate \\
& Material updates & 4 & Very appropriate \\
\hline \multirow{5}{*}{ Feasibility of presentation } & Encourage curiosity & 4 & Very appropriate \\
& Presentation technique & 3,67 & Appropriate \\
& Presentation support & 4 & Very appropriate \\
& Presentation of learning & 3,5 & Appropriate \\
\hline \multirow{5}{*}{ Language eligibility } & Coherence and wrinkling of thought lines & 3,67 & Appropriate \\
& Straightforward & 3 & Appropriate \\
& Communicative & 4 & Very appropriate \\
& Dialogical and Interactive & 4 & Very appropriate \\
& Conformity with the development of students & 3,5 & Appropriate \\
\hline
\end{tabular}


Table 3. Results of expert validator assessment media

\begin{tabular}{llcl}
\hline \multicolumn{1}{c}{ Indicator } & \multicolumn{1}{c}{ Point of Assessment } & Score & Category \\
\hline Size of practicum & Compliance with ISO & 4 & Appropriate \\
instructions & Conformity with material & 4 & Very appropriate \\
\hline \multirow{3}{*}{ Cover design } & Layout & 4 & Very appropriate \\
& Colour & 4 & Very appropriate \\
& Letter & 4 & Very appropriate \\
& Letter Combination & 4 & Very appropriate \\
& Cover Illustration & 4 & Very appropriate \\
\hline \multirow{3}{*}{ Content design } & Layout consistency & 4 & Very appropriate \\
& Layout harmonization & 4 & Very appropriate \\
& Complete layout & 4 & Very appropriate \\
& The layout accelerates the page & 4 & Very appropriate \\
& Simple content typography & 4 & Very appropriate \\
& Typography content makes it easy to understand & 4 & Very appropriate \\
& Content illustration & 4 & Very appropriate \\
\hline \multirow{2}{*}{ Learning Activities } & Conformity with guided inquiry syntax & 4 & Very appropriate \\
& Able to encourage students to do scientific work & 4 & Very appropriate \\
\hline
\end{tabular}

Table 4. Results of practitioner assessment field

\begin{tabular}{llcl}
\hline \multicolumn{1}{c}{ Aspect } & \multicolumn{1}{c}{ Indicator } & Score & Category \\
\hline \multirow{4}{*}{ Feasibility of content } & 3 & Appropriate \\
& Components of practicum instructions & 3 & Appropriate \\
& Curriculum & 3,67 & Appropriate \\
& Meaningfulness & 3,67 & Appropriate \\
& Title Determination & 4 & Very appropriate \\
\hline \multirow{2}{*}{ Grammar } & Writing & 3 & Appropriate \\
& Use The Indonesian Language well and correctly & 3 & Appropriate \\
\hline \multirow{2}{*}{ Display } & Communicative and straightforward language & 3 & Appropriate \\
& Interesting & 3 & Appropriate \\
\hline
\end{tabular}

Based on Table 4, it could be seen that the average score for the aspect of feasibility of content is 3.45 in the appropriate category, the grammar aspect is 3 in the appropriate category, and the aspect of appearance is 3 in the appropriate category. Suggestions for product development are products should use more coherent sentences. The conclusion of product development was that products could be used with revisions.

Table 5 obtained the results of the assessment of the validator material experts with a percentage of $93.48 \%$ with a very feasible category. The things that need to be revised based on the validator material expert was the practicum guidebook should be equipped with the introduction of laboratory materials and their usefulness, added a bibliography in each chapter, in the table of contents written in detail the title of each chapter and official report format added bibliography and interim reports. Assessment results from media expert validators with a percentage of $100 \%$ with a very feasible category. Assessment results from field practitioners with a percentage of $81.5 \%$ with very feasible categories. The thing that needs to be revised based on the field practitioner was that the practical guide should use more coherent sentences. The results of the product readability test assessment (Table 6) got a percentage of $61.67 \%$ answering strongly agree and $31.67 \%$ answered agree. Based on the summary of assessment results validator (Table 7) it was found that the biochemistry practicum guide received a very feasible category readability category.

Practicum is a series of activities that enable a person (student) to apply skills or practice something (Zulaiha \& Ibrahim, 2014). The objectives of the practicum include motivating students, teaching basic scientific skills, increasing understanding of concepts, understanding and using scientific methods, and developing scientific attitudes (Nengsi, 2016).

Practicum activities can run smoothly if there are teaching materials in the form of a practical guide or practicum instructions. Practicum instructions are one of the supporting activities for practicum (Putri, Hasnunidah, \& Yolida, 2018). The appointment of the practicum was 
compiled and written by a group of teaching staff who handled the practicum and followed scientific writing rules.

Practicum activities was one of the scientific work manifestation in learning. Practicum activities are experiments displayed by teachers in the form of demonstrations, demonstrations cooperatively by a group of students, as well as experiments and observations by students. These activities can take place in the laboratory or elsewhere (Salirawati, 2010).

Table 5. Percentage of test result product readability

\begin{tabular}{lcccc}
\hline \multirow{2}{*}{ Aspect } & \multicolumn{3}{c}{ Assessment } \\
\cline { 2 - 5 } & Strongly agree & Agree & Disagree & Strongly disagree \\
\hline Display & 58 & 27 & 0 & 0 \\
Material & 57 & 46 & 0 & 0 \\
Benefits & 70 & 22 & 0 & 0 \\
\hline Average $(\%)$ & 61.67 & 31.67 & 0 & 0 \\
\hline
\end{tabular}

Table 6. Summary of assessment results validator

\begin{tabular}{lcc}
\hline \multicolumn{1}{c}{ Assessment } & Percentage (\%) & Category \\
\hline Expert material validator & 93.48 & Very decent \\
Media expert validator & 100 & Very decent \\
Field practitioner & 81.5 & Very decent \\
\hline
\end{tabular}

Table 7. Summary of product revision based on advice from validators

\begin{tabular}{lll}
\hline \multicolumn{1}{c}{ Assessment } & \multicolumn{1}{c}{ Before Revision } & \multicolumn{1}{c}{ After Revision } \\
\hline Expert material & The practicum guidebook has not been & The practicum guidebook has been \\
equipped with the introduction of & equipped with the introduction of \\
& laboratory materials and their uses & laboratory materials and their uses \\
& There is no bibliography in each chapter & There is a bibliography in each chapter \\
& $\begin{array}{l}\text { The table of contents has not been written } \\
\text { with the detailed title of each chapter }\end{array}$ & $\begin{array}{l}\text { The table of contents has been written } \\
\text { with the detailed title of each chapter }\end{array}$ \\
& $\begin{array}{l}\text { The official report format has no } \\
\text { bibliography and temporary reports }\end{array}$ & $\begin{array}{l}\text { Official report format plus bibliography } \\
\text { and interim reports }\end{array}$ \\
\hline Field practitioner & Don't use more coherent sentences & Already using more coherent sentences \\
\hline
\end{tabular}

The practicum guidebook developed has features compared to others, namely guided inquiry-based. Inquiry that is guided by an instructional team to enable students to gain a depth of understanding and a personal perspective through a wide range of sources of information is called Guided Inquiry. Guided Inquiry equips students with abilities and competencies to address the challenges of an uncertain, changing world. Teachers cannot do this task or activity alone.

Guided Inquiry is a way of learning that accomplishes the objectives of $21^{\text {st-century }}$ schools. It is the way to meet the many requirements of the curriculum through engaging, motivating and challenging learning. Teachers and librarians work together to guide students thinking and learning through inquiry (Kuhlthau, Maniotes, \& Caspari, 2007). The guided inquiry design process are open (an issue or contextual thing), immerse, explore, identify, gather, create and share, evaluate (Maniotes \& Kuhlthau, 2014).
Guided inquiry is an effective learning model that helped teachers in motivating students to ask questions that were an important part of inquirybased learning. In addition, the guided inquiry model could increase students' self-confidence and student learning achievement. Biochemistry course was a subject that was difficult to understand by students, especially practicum activities. The guided inquiry was a learning model that was able to hone students' ability worked scientifically through investigation with coherent stepped so as facilitated students in carrying out practicum.

\section{CONCLUSION}

It could be concluded that the guided inquirybased biochemistry practicum guidebook is highly suitable to be implemented in learning process. However, the practicum guidebook still needed to be further investigated regarding the dissemination. 


\section{ACKNOWLEDGMENT}

Thank you to the Ministry of Research, Technology, and Higher Education of Indonesia and the Rector of IKIP Budi Utomo Malang for giving the opportunity to participate in the Beginner Lecturer Research Program with the contract number 85/IKIP-BU/III/2018 in 2018.

\section{REFERENCES}

Almuntasheri, S., Gillies, R. M., \& Wright T. (2016). The effectiveness of a guided inquiry-based, teachers' professional development programme on Saudi students' understanding of density. Science Education International, 27(1), 16-39.

Garrison, K., \& FitzGerald, L. (2016). "It's like stickers in your brain" Using the guided inquiry process to support lifelong learning skills in an australian school library. In International Association of School Librarianship Annual Conference 2016 (pp. 1-18). Brantford: International Association of School Librarianship.

Ibe, H. (2013). Effects of guided-inquiry and expository teaching methods on senior secondary school students' performances in Biology in Imo State. Journal of Education Research and Behavioral Sciences, 2(4), 51-57.

Joyce, B., \& Weil, M. (2000). Models of teaching (5th ed.). Prentice-hall of India.

Kuhlthau, C. C., Maniotes, L. K., \& Caspari, A. K. (2007). Guided inquiry learning in the 21 st century. USA: Libraries Unlimited.

Maniotes, L. K., \& Kuhlthau, C. C. (2014). Making the shift: From traditional research assignments to guiding inquiry learning. Knowledge Quest, 43(2), 8-17.

Munika, M., Mujamil, J., \& Desi, D. (2014). Pengembangan petunjuk praktikum larutan asam basa berbasis inquiry pada mata kuliah praktikum kimia dasar II di FKIP Universitas Sriwijaya. Palembang. Retrieved from http://ejournal.unsri.ac.id/ index.php/jurpenkim/article/view/1896

Munir, M., \& Sholehah, H. (2018). Pengembangan petunjuk praktikum Matlab dan uji efektivitasnya pada mahasiswa semester IV Jurusan Pendidikan Matematika IAIN Mataram. Jurnal Ai-Muta'aliyah STAI Darul Kamal NW Kembang Kerang, I(3), 56-69.
Nengsi, S. (2016). Pengembangan penuntun praktikum biologi umum berbasis inkuiri terbimbing mahasiswa biologi STKIP Payakumbuh. Jurnal IPTEKS Terapan, 10(1), 47-55. https://doi.org/10.22216/jit. 2016.v10i1.343

Putri, Z. M., Hasnunidah, N., \& Yolida, B. (2018). Pengembangan buku penuntun praktikum struktur dan fungsi tumbuhan dengan model argument-driven inquiry (ADI). Bioterdidik, 1(1). Retrieved from http://jurnal.fkip.unila.ac.id/index.php/JB T/article/view/15195

Sadjati, I. M. (2012). Pengembangan bahan ajar. In Hakikat bahan ajar. Jakarta: UT.

Salirawati, D. (2010). Optimalisasi pendidikan nilai/karakter dalam pendidikan kimia masa depan. In Seminar Nasional Kimia: Profesionalisme Peneliti dan Pendidik dalam Riset dan Pembelajaran Kimia yang Berkualitas dan Berkarakter. Yogyakarta: Pendidikan Kimia UNY.

Sandika, B., \& Fitrihidajati, H. (2018). Improving creative thinking skills and scientific attitude through inquiry-based learning in basic biology lecture toward students of biology education. JPBI (Jurnal Pendidikan Biologi Indonesia), 4(1), 23-28. https://doi.org/10.22219/jpbi. v4i1.5326

Sugiyono, S. (2011). Metode penelitian kuantitatif, kualitatif dan R\&D. Bandung: Alfabeta.

Suryaningsih, Y. (2017). Pembelajaran berbasis praktikum sebagai sarana siswa untuk berlatih menerapkan keterampilan proses sains dalam materi biologi. Bio Educatio, 2(2), 49-57.

Thiagarajaan, S., Semmel, D. G., \& Semmel, M. I. (1974). Instructional development for training teachers of exceptional children: A sourcebook. Indiana: Center for Innovation in Teaching the Handicapped.

Wahyuni, S. (2015). Pengembangan petunjuk praktikum IPA untuk meningkatkan kemampuan berpikir kritis siswa SMP. Jurnal Pengajaran MIPA, 20(2), 196203.https://doi.org/10.18269/jpmipa.v20i 2.585

Zulaiha, H., \& Ibrahim, A. R. (2014). Keterampilan proses sains di SMA. Palembang. Retrieved from ejournal.unsri. ac.id/index.php/jurpenkim/article/view/22 28 